\title{
A Taiwanese Perspective on Henry James: An interview with Doctor Sherry Li
}

DOI: http://dx.doi.org/10.12775/LC.2017.017

Grzegorz Koneczniak: Thank you very much for agreeing to answer a few questions about Henry James. To start off, perhaps you could tell us something about your academic experience and research areas?

Dr Sherry Li: I received my Ph.D. in English from the State University of New York at Buffalo, where I wrote my Ph.D. dissertation on W. D. Howells, Theodore Dreiser and Edith Wharton. Since graduation, I have been teaching at the Department of Foreign Languages and Literatures in National Taiwan University. My research interests are social class and power relations in American Realist novels. I have mainly been teaching undergraduate American Literature survey courses and occasionally late nineteenth-century American fiction in the M.A. program.

And how about your experience in teaching and researching American literature and works by such writers as James?

I have been teaching our undergraduate American literature survey course for over a dozen years, and I have discussed Henry James every year. I have also taught a graduate course on late nineteenth-century American fiction a few times and included James' works-usually The Portrait of a Lady. Among the journal articles and book chapters I have published, I have written about "The Real Thing," "The Ghostly Rental” and The Turn of the Screw.

The next question is about your personal opinion. What is your perception of Henry James's works? Are they still relevant in the twenty-first century and one hundred years after James's death? Which of his works is your favourite one?

James's portrayal of human psychology and interpersonal relationships will always be relevant. His exploration of issues related to artistic creations are also timeless. His works have a wealth of socio-cultural details that also work well in cultural-studies projects. I love so many of his works, and then there are also many I have not read, so I hesitate to name any of them as my favorite. 
And how would you comment on the presence of Henry James studies in Taiwan? In general, we have fewer American literature scholars than English literature specialists, and then the earlier periods are less popular than contemporary periods. James studies is therefore not especially prominent in Taiwan. On the other hand, James is well-known and well-respected, so with every new academic trend, some scholar will try to use his work as their research subject if it fits. A search of the databases shows that we have over thirty papers on James in our local research journals since 1975, and nearly as many M.A. theses or Ph.D. dissertations since 1979.

Dr. Li, do you think it is possible to enumerate some common perspectives from which Henry James's works have been analysed by scholars in Taiwan?

Most scholars in Taiwanese academia have a training in comparative literature or literary theory/cultural studies. Therefore, besides the earlier thematic and formalistic approaches, more recent studies are informed by the researcher's own interest in, for instance, exchange economy, psychoanalysis, bodily practices, visual studies, urban culture, the gothic, philosophy, etc.

I'm interested in this distinction between "thematic and formalistic approaches." Could you elaborate on the two in the context of James's works?

For lack of a better word, perhaps, by "thematic approaches" I had in mind for instance journal papers on "paternal protection" in Washington Square, and on "emotional fraud" in The Wings of the Dove. By "formalistic approaches," I meant papers on The Portrait of a Lady as Bildungsroman, and on "the art of contrast" in his works.

And what are your impressions concerning the reception and criticism of James's works? Is it possible to enumerate any major Jamesian scholars or doyens of Jamesian research in Taiwan?

The common impression of James's fiction is that it is psychologically profound, stylistically sophisticated, but difficult to read. He is highly respected as an author, but also considered a challenge to the average reader. The only scholar I know who has specialized in James would be Professor Wu, Ta-cheng, from our department, but he retired in 1997. His background is in philosophy, so his research leans in that direction. Younger scholars specializing in the period have probably written about James at some point, though none of them are as exclusively devoted to James as Prof. Wu.

I suppose English departments in Taiwan have survey courses in American literature. Are James's works included? If so, which of his works are frequently discussed with students?

Most English departments in Taiwan have an American Literature survey course, but depending on class time and the instructor's emphasis, not all of their syllabi include James. The most often read works seem to be "Daisy Miller" and "The Real Thing." 
And how are James's works perceived by students in general?

In reading "Daisy Miller," students usually focus on individualism vs. conformity, and often take a feminist stance. This probably has to do with their recognition of the tension between the conservative traditional values in Taiwan and the westernized modern culture.

So it means that the students are aware of the difference between "the conservative values in Taiwan and the westernised modern culture." Am I right?

Yes, the mainstream values of Taiwan are still rather conservative and thus closer to the Victorian period, for instance the behavior codes in courtship, gender roles, double standards, harmony within the community, the pressures of conformity, deference to the older generation, etc. But we have also been heavily influenced by western culture; the younger generation, especially English majors, subscribe to ideas like individualism, gender equality, sexual freedom, etc. The students can therefore sympathize with the tension between Daisy and the other characters. Also, most of our students are women, so they can relate to her. On the other hand, "The Real Thing" will get them thinking about the relation between art and reality. Graduate students will take what theory they happen to be studying-psychoanalysis, phenomenology, feminism, visual culture, etc.- - and connect it with the works.

The next question refers to the publishing and editorial presence of James's works in Taiwan. How would you comment on the availability of James's texts in original versions and translations?

The original versions are mostly read by English majors. There are several translations of The Portrait of a Lady and The Turn of the Screw, which are still widely available. Lately there has been a translation of What Maisie Knew (because of the movie, and still available) and a collection of tales that includes translations of "Daisy Miller," "The Pupil," "The Figure in the Carpet," and "The Beast in the Jungle," which is out of print.

And how would you assess the existing translations of James's works? Do you think there still much translation work to be done?

As with all translations, there is still much to be desired, especially given the subtlety and complexity of James's language. As shown above, very few of his works have been translated, and much more could be done.

And how about your experience as regards translating James's works?

I have only translated a few sentences from his work for my articles. For me the most difficult part is trying to retain the complex structure and flow of his sentences. Many of the Chinese translations just try to get the meaning right and can't reflect his style-even getting the meaning right isn't always easy, because many translators have a hard time figuring out the complex syntax and who/what his pronouns refer to.

Are you planning to do research on James? If so, which aspects do you find worth studying?

I would surely like to do further research on James' works, although I don't have any immediate projects. I do have plans to offer an undergraduate course of his short stories in the 
near future, through which I hope to find inspiration for further research and at the same time introduce him to more students.

Interview by Grzegorz Koneczniak*

* Assistant Professor in the English Department of Nicolaus Copernicus University in Toruń, where he teaches editorial and textual aspects of literary works. His research interests also include postcolonial literatures, postcolonial theatre (Canadian and Irish), Anglo-Irish literature, literary theory, and comparative studies. E-mail: gregorex@umk.pl. 